\title{
Persistent Sydenham's chorea is not associated with sustained lymphocyte dysfunction
}

\author{
A coreia de Sydenham persistente não está associada à disfunção sustentada de linfócitos \\ Karen Cecillia de Lima Torres', Natália Pessoa Rocha², Vitor Bortolo de Rezende1, Walderez Ornelas Dutra \\ Kenneth John Gollob4 ${ }^{4}$ Francisco Cardoso ${ }^{5}$, Antonio Lucio Teixeira ${ }^{2,5}$
}

\begin{abstract}
The mechanisms involved in the symptoms of Sydenham's chorea (SC) remain obscure. Taking into account the autoreactive antibody-mediated hypothesis of SC pathogenesis, the persistence of chorea may be associated with increased levels of B1 lymphocytes and other lymphocyte subsets. We evaluated lymphocyte subsets, including B1 and T cells, in patients with remitted (RSC) and persistent (PSC) SC by flow cytometry. Our results showed neither difference in the frequency of T and B lymphocytes subpopulations nor in their activation and functional states. These findings undermine the view of PSC as a sustained cytotoxic cellular-mediated condition. Alternative mechanisms may explain the pathogenesis of PSC.
\end{abstract}

Keywords: Sydenham chorea, autoimmunity, lymphocytes, B1 cells.

\section{RESUMO}

Os mecanismos subjacentes aos sintomas da coreia de Sydenham (CS) permanecem desconhecidos. Considerando-se a hipótese de que a patogênese da CS é mediada por anticorpos autorreativos, a persistência da coreia está provavelmente associada a níveis aumentados de linfócitos B1 e outros subtipos de linfócitos. No presente trabalho, foram avaliados subtipos de linfócitos B e T em pacientes com CS em remissão (CSR) e persistente (CSP), por citometria de fluxo. Nossos resultados demonstraram que não há diferença na frequência das subpopulações de linfócitos T e B circulantes e no perfil de ativação e estado funcional dessas células. Esses resultados enfraquecem a hipótese de que a CSP seja uma condição imune sustentada mediada por células citotóxicas. São necessários estudos que investiguem mecanismos alternativos que expliquem a patogênese da CSP.

Palavras-chave: coreia de Sydenham, autoimunidade, linfócitos, células B1.

Sydenham's chorea (SC) is the most common cause of chorea in developing countries ${ }^{1}$. Apart from chorea, SC patients can exhibit other motor symptoms such as dysarthria and decreased muscle tone. Psychiatric syndromes can also be present, including attention deficit hyperactivity disorder, and obsessive-compulsive disorder ${ }^{2,3}$.

SC is the late neurological manifestation of Group A beta-hemolytic streptococcal oropharynx infection and one of the major criteria for the diagnosis of rheumatic fever ${ }^{4}$. Despite the well-known relationship between streptococcal infection and rheumatic fever, the precise pathogenesis of SC remains a matter of debate. One of the most attractive hypotheses proposes that SC is an autoimmune disorder resulting from cross-reactive antibodies against basal ganglia neurons. Autoimmune mechanisms underlying SC pathophysiology are strongly supported by a range of evidence. Studies have reported increased levels of cytokines in serum and cerebrospinal fluid of SC patients in comparison with controls ${ }^{5,6}$, as well as the presence of circulating anti-basal ganglia antibodies (ABGA) in SC patients ${ }^{5,7}$. Chorea and other motor symptoms of acute SC improve after immune-modulatory therapy ${ }^{8}$. In vitro studies showed that SC autoantibodies may influence neuronal cell signaling, impairing CNS functioning ${ }^{9,10}$. Furthermore, rats receiving

1Fundação Osvaldo Cruz, Centro de Pesquisas René Rachou, Belo Horizonte MG, Brazil;

Universidade Federal de Minas Gerais, Faculdade de Medicina, Laboratório Interdisciplinar de Investigação Médica, Belo Horizonte MG, Brazil;

${ }^{3}$ Universidade Federal de Minas Gerais, Instituto de Ciências Biológicas, Departamento de Morfologia, Belo Horizonte MG, Brazil;

${ }^{4}$ Hospital Santa Casa de Belo Horizonte, Programa de Pós-graduação em Biomedicina e Medicina do Instituto de Ensino e Pesquisa, Belo Horizonte MG, Brazil;

5Universidade Federal de Minas Gerais, Faculdade de Medicina, Departamento de Clínica Médica, Belo Horizonte MG, Brazil.

Correspondence: Antônio Lúcio Teixeira; Faculdade de Medicina da UFMG, Laboratório Interdisciplinar de Investigação Médica; Avenida Prof. Alfredo Balena, 190 / sala 281;30130-100 Belo Horizonte MG, Brasil; E-mail: altexr@gmail.com

Conflict of interest to declare: There is no conflict of interest to declare.

Support: Conselho Nacional de Desenvolvimento Científico e Tecnológico (CNPq), Fundação de Amparo à Pesquisa do Estado de Minas Gerais (Fapemig).

Received 08 June 2015; Received in final form 11 June 2015; Accepted 01 July 2015. 
intra-striatal sera from SC patients displayed higher number of contralateral rotations after apomorphine (dopamine agonist) injection than those receiving control sera ${ }^{11}$. Together these findings suggest that ABGA may cause motor changes probably by stimulating dopaminergic receptors in the basal ganglia.

SC is traditionally regarded as a self-limited disorder with spontaneous remission after a course of 6 to 9 months (remitted SC; RSC). Nevertheless, a significant number of SC patients remains with chorea on long-term follow-up (i.e. over 2 years), what is called persistent SC (PSC). Proposed mechanisms involved in the persistence of chorea include irreversible basal ganglia damage during the acute phase of the disease or sustained pathological immune response ${ }^{12}$.

B1 cells are a subset of B lymphocytes that produce antibodies that are frequently auto-reactive. The frequency of circulating B1 cells is very low in healthy subjects but tends to be elevated in patients with autoimmune diseases ${ }^{13}$. Considering the auto-reactive antibody-mediated hypothesis of SC pathogenesis, PSC may be associated with increased frequency of circulating B1 cells. Accordingly, the current study aimed at evaluating circulating lymphocyte subsets and their activation and functional states in RSC and PSC in comparison with control subjects.

\section{METHOD}

\section{Subjects}

Fourteen subjects over 16 years-old were recruited for this study: 5 PSC patients (M/F, 4/1; mean age \pm SD, $24.7 \pm 8.6)$; 9 RSC patients (M/F, 5/4; mean age \pm SD, $25.4 \pm 11.5)$ and 12 age and gender-matched healthy individuals (M/F, 8/4; mean age $\pm \mathrm{SD}, 24.0 \pm 5.8$ )

$\mathrm{SC}$ was diagnosed in patients fulfilling the modified Jones Criteria for rheumatic fever ${ }^{14}$ after the careful exclusion of alternative causes of chorea ${ }^{4}$. At diagnosis, all patients had ecocardiographic signs of carditis represented by mild mitral insufficiency. The definition for persistent SC was chorea lasting more than 2 years regardless of the use of antichoreic drugs ${ }^{12}$. Control subjects had no current clinical disease and/or previous history of rheumatic fever.

\section{Flow cytometry analyses}

Blood was aseptically collected in heparinized tubes. Peripheral blood mononuclear cells (PBMC) were obtained using a Ficoll-Hypaque (Sigma-Aldrich, St. Louis, MO, USA) gradient. Cells $\left(2 \times 10^{5}\right)$ were stimulated with anti-CD3 monoclonal antibodies (1 mg/mL) (BD Biosciences, San Jose, CA, USA) and anti-CD28 monoclonal antibodies $(0.5 \mathrm{mg} / \mathrm{mL})$ (BD Biosciences) in RPMI 1640 (Sigma-Aldrich) supplemented with $5 \%$ heat-inactivated human serum (Sigma-Aldrich), $1 \mathrm{mM}$ of L-glutamine and antibiotics 200U of penicillin (Sigma-Aldrich). Cultures were harvested following $18 \mathrm{~h}$ of stimulation.
Cells were then stained with fluorescein isothiocyanate (FITC) and phycoerytrin (PE)-labeled antibody solutions for 20 min at $4^{\circ} \mathrm{C}$. Then, PBMC were washed with $0.1 \%$ sodium azide PBS (Sigma-Aldrich), and fixed with $2 \%$ formaldehyde in PBS. The antibodies used for staining were specific monoclonal antibodies directed to CD4, CD8, CD5, CD19, CD25, CD69 and CD45RO surface antigens. All antibodies used were from BD Biosciences.

FITC and PE-labeled immunoglobulin isotype control antibodies were included in all experiments. The stained cells were acquired using a FACScan flow cytometer with an air-cooled argon laser (BD Biosciences). Analyses were performed using CellQuest (BD Biosciences) and FlowJo (Tree-Star Inc., Ashland, OR, USA) software, in order to perform the representative dot plots. Leukocytes were analyzed for the frequencies of surface markers expression. The frequency of positive cells was analyzed inside the lymphocyte gate. Limits for the quadrant markers were always set based on negative populations and isotype controls.

Results are shown as means \pm standard deviations (SD). Differences among groups were tested using Kruskal-Wallis test with Dunn's Multiple Comparison post-test. Statistical analyses were performed using GraphPad Prism (GraphPad Software, La Jolla, CA) with a significance level of $\alpha$ set at 0.05 .

\section{RESULTS}

Initiallywe evaluated the frequencyofBandTlymphocytes. We found no differences between RSC patients, PSC patients and controls regarding the percentages of $\mathrm{B}$ cells (CD19+) (Figure 1A: mean \pm SD, RSC $=9.10 \pm 4.33 \%$; PSC $=10.57 \pm 3.41 \%$ and controls $=8.51 \pm 2.74)$, and B1 lymphocytes (CD19+CD5+) (Figure 1B: RSC $=0.54 \pm 0.23 \%$, PSC $=0.57 \pm 0.25 \%$ and controls $=0.54 \pm 0.21 \%$ ). The percentage of CD4+ T lymphocytes (Figure 1C: $\mathrm{RSC}=46.59 \pm 10.84 \%$; PSC $=50.73 \pm 4.71 \%$ and controls $=41.91 \pm 10.39 \%$ ) and CD8 $+\mathrm{T}$ lymphocytes (Figure 1D: $\mathrm{RSC}=16.82 \pm 6.68 \%, \mathrm{PSC}=17.45 \pm 5.12 \%$ and controls $=19.81 \pm 8.63 \%$ ) were also similar among the three evaluated groups.

To investigate lymphocyte activation and functional profiles, we analyzed the expression of the surface markers of recent and chronic activation (CD69 and CD25, respectively) in CD4+ and CD8+ $\mathrm{T}$ lymphocytes (Figure 2). Here again, we found no differences among the three evaluated groups of subjects (PSC, RSC and controls). The frequencies of CD4+CD25+ T cells (Figure 2A) were RSC $=3.30 \pm 1.18 \%$, $\mathrm{PSC}=3.65 \pm 1.06 \%$ and controls $=2.95 \pm 1.16 \%$. The percentages of $\mathrm{CD} 8+\mathrm{CD} 25+\mathrm{T}$ cells are given in Figure $2 \mathrm{~B}(\mathrm{RSC}=0.68 \pm 0.37 \%$; $\mathrm{PSC}=0.40 \pm 0.30 \%$ and controls $=0.76 \pm 0.65 \%$ ). Figure $2 \mathrm{C}$ shows the percentages of $\mathrm{CD} 4+\mathrm{CD} 69+\mathrm{T}$ cells $(\mathrm{RSC}=0.80 \pm 0.38 \%$; PSC $=0.90 \pm 0.50 \%$ and controls $=1.07 \pm 0.90 \%)$. Lastly, the percentages of $\mathrm{CD} 8+\mathrm{CD} 69+\mathrm{T}$ cells are shown in 
Figure 1D $(\mathrm{RSC}=1.76 \pm 1.42 \%$; PSC $=0.80 \pm 0.30 \%$ and controls $=1.91 \pm 1.32 \%)$.

We also evaluated a surface marker of memory (CD45RO) in CD4+ and CD8+ T lymphocytes. No differences were found among groups. The percentages of $\mathrm{CD} 4+\mathrm{CD} 45 \mathrm{RO}+$ and $\mathrm{CD} 8+\mathrm{CD} 45 \mathrm{RO}+$ memory $\mathrm{T}$ cells are given in Figure $1 \mathrm{E}(\mathrm{RSC}=22.34 \pm 10.16 \%$; PSC $=24.32 \pm 8.85 \%$ and controls $=21.02 \pm 10.19 \%)$ and Figure $1 \mathrm{~F}(\mathrm{RSC}=5.76 \pm 4.53 \%$; $\mathrm{PSC}=3.85 \pm 2.61 \%$ and controls $=4.79 \pm 3.33 \%$ ), respectively.

Additionally, we found no differences when analyzing PBMC cultured under the presence or not of polyclonal (anti-CD3/CD28) stimuli (data not shown).

\section{DISCUSSION}

We designed this study primarily to investigate a possible role of lymphocytes in the development and/or persistence of chorea in SC. We found no differences among groups in all of the evaluated immunological parameters. To the best of our knowledge, this is the first study assessing lymphocyte subsets in SC.

More specifically, we were interested in assessing CD4+ and CD8+ T lymphocytes as well as B1 cells in SC patients in comparison with asymptomatic subjects. While CD4+ T cells are involved in the orchestration of immune response, CD8+ T cells can promote target cells destruction ${ }^{15}$. Changes in lymphocyte profile may be associated with a series of autoimmune disorders. In the case of SC, this is particularly relevant for B1 cells that are involved in antibody-mediated autoimmune conditions ${ }^{13}$. Our results failed to demonstrate any significant difference between patients and controls in the composition of lymphocyte subsets, indicating that there is no evidence of sustained lymphocyte activation in PSC. Our work group has previously described a decrease in the percentage of CD14+ monocytes in the peripheral blood of SC patients. In addition, we observed reduced frequency of CD14+CD86+ and CD14+HLA-DR+ cells in SC, indicating that monocytes might play a role in the immune mechanisms underlying SC pathogenesis ${ }^{16}$.

Non-immune mechanisms may be associated with the pathogenesis of PSC. Basal ganglia structural damage may occur during the acute phase of SC, leading to persistent involuntary choreic movements in a subgroup of patients. In line with this hypothesis, neuroimaging studies have demonstrated that patients who remitted completely their choreic movements did not present lesions of the basal ganglia
A

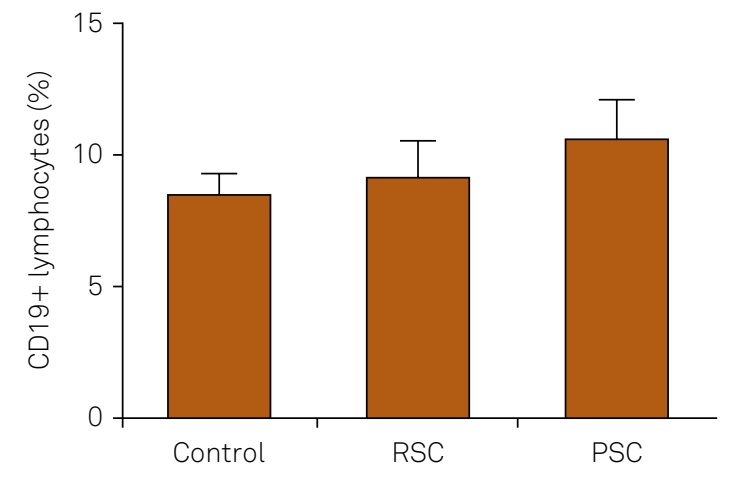

C

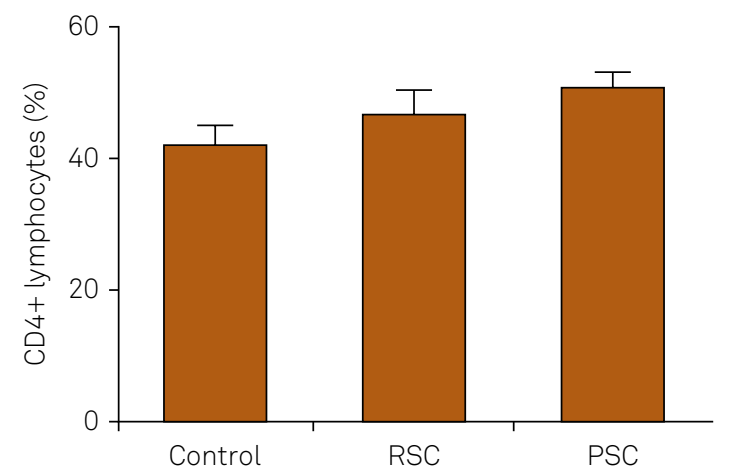

B

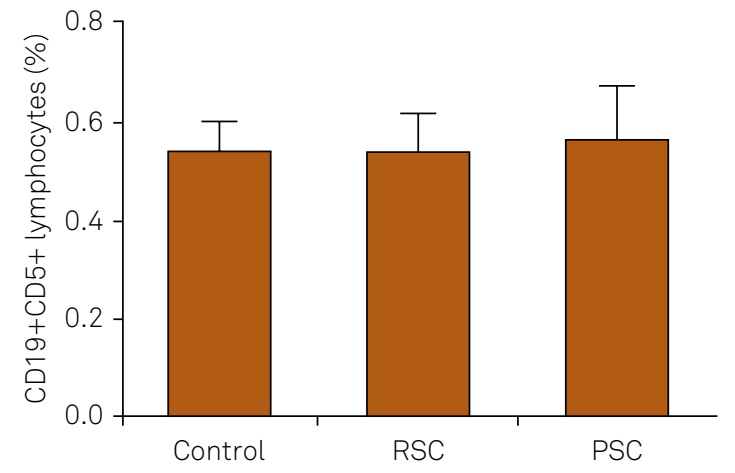

D

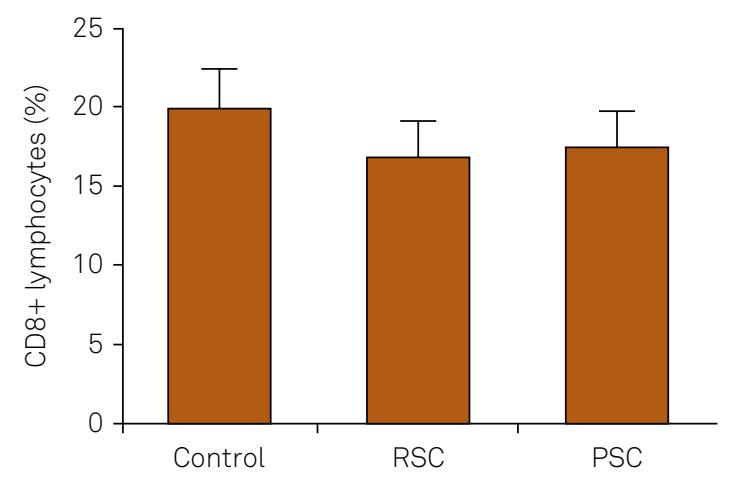

Figure 1. T and B lymphocyte frequencies of SC patients and controls. (A) percentage of B (CD19+) cells expression; (B) percentage of B1 cells expression (CD19+ CD5+); (C) frequency CD4+ T lymphocytes expression; (D) percentage of CD8+ T lymphocytes expression. RSC = remitted Sydenham's chorea; PSC = persistent Sydenham's chorea. 
A

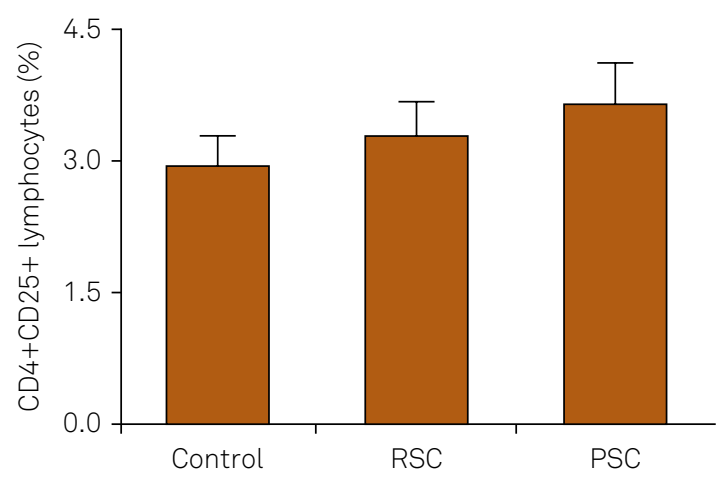

C

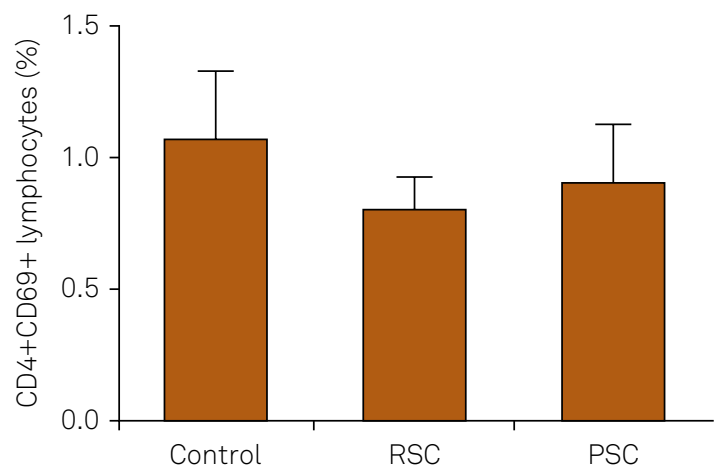

E

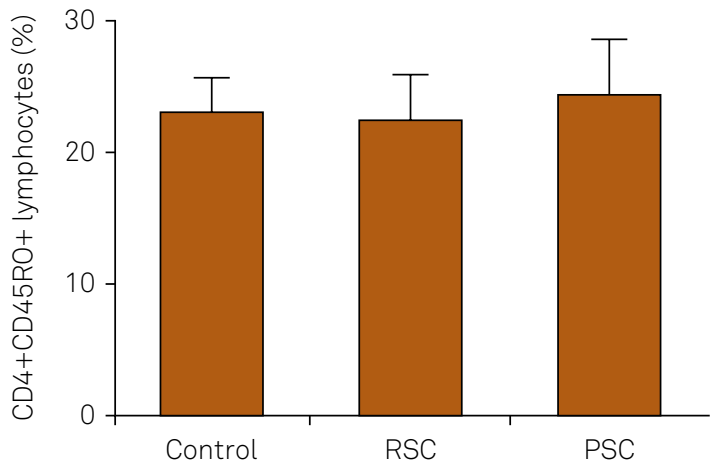

B

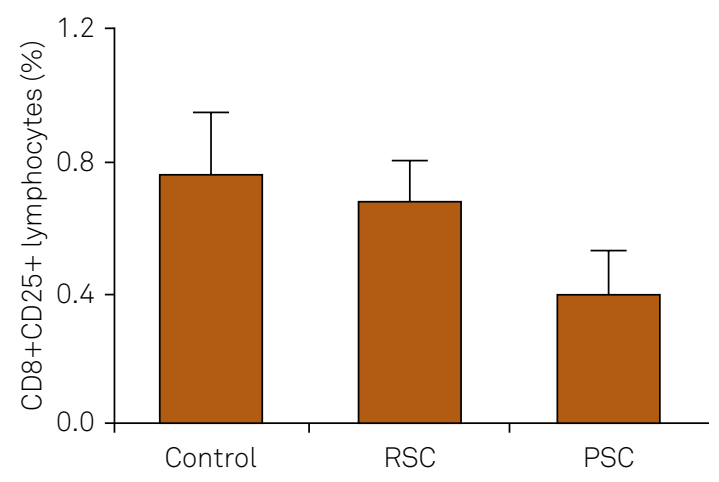

D

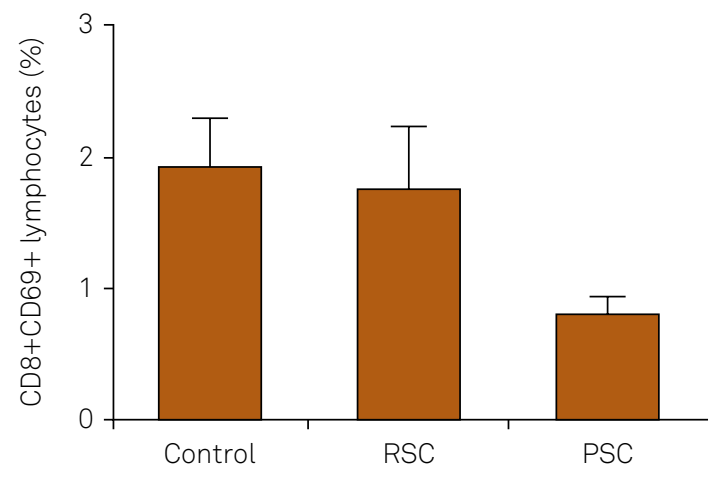

$\mathbf{F}$

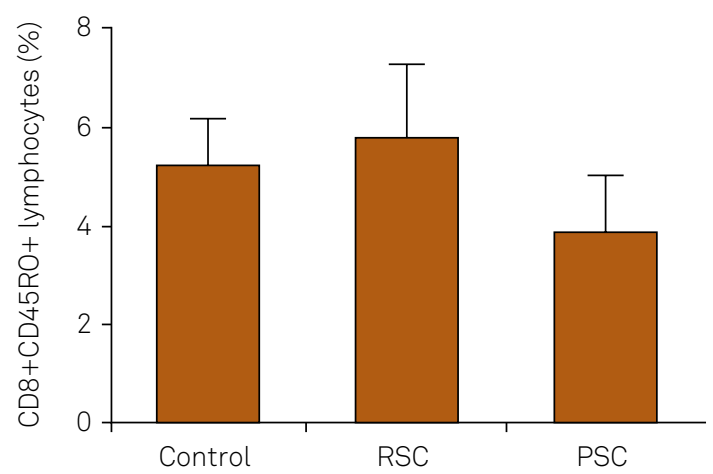

Figure 2. Activation and functional state of lymphocytes of SC patients and controls. (A) percentage of CD4+CD25+ T cells; (B) percentage of CD8+ CD25+ T cells expression; (C) frequency of CD4+ CD69+ T lymphocytes expression; (D) frequency of CD8+ CD69+ T lymphocytes expression; (E) frequency of CD4+ CD45RO+ memory T cells; (F) CD8+ CD45RO+ memory T cells expression. $\mathrm{RSC}=$ remitted Sydenham's chorea; PSC = persistent Sydenham's chorea.

after the acute phase of the disease. Conversely, patients with persistent basal ganglia lesions were more prone to develop recurrences of chorea ${ }^{17}$.

Altogether, our data suggest that the persistence of choreic involuntary movements in SC is not associated with persistent lymphocyte dysfunction. Specially, the percentage of B1 cells - a subset of B lymphocytes increased in autoimmune conditions - are not changed in RSC or PSC. Therefore, patients with persistent SC may not be candidates for immunosuppressive or immunomodulatory therapies. 
1. Cardoso F. Chorea: non-genetic causes. Curr Opin Neurol. 2004;17(4):433-6. doi:10.1097/01.wco.0000137533.53620.59

2. Maia DP, Teixeira AL, Quintão Cunningham MC, Cardoso F. Obsessive compulsive behavior, hyperactivity, and attention deficit disorder in Sydenham chorea. Neurology. 2005;64(10):1799-801. doi:10.1212/01.WNL.0000161840.62090.0E

3. Teixeira AL, Maia DP, Cardoso F. UFMG Sydenham's chorea rating scale (USCRS): reliability and consistency. Mov Disord. 2005;20(5):585-91. doi:10.1002/mds.2037

4. Cardoso F, Eduardo C, Silva AP, Mota CC. Chorea in fifty consecutive patients with rheumatic fever. Mov Disord. 1997;12(5):701-3. doi:10.1002/mds.870120512

5. Church AJ, Dale RC, Cardoso F, Candler PM, Chapman MD, Allen ML et al. CSF and serum immune parameters in Sydenham's chorea: evidence of an autoimmune syndrome? J Neuroimmunol. 2003;136(1-2):149-53. doi:10.1016/S0165-5728(03)00012-2

6. Teixeira AL, Cardoso F, Souza AL, Teixeira MM. Increased serum concentrations of monokine induced by interferon-gamma/ CXCL9 and interferon-gamma-inducible protein 10/CXCL-10 in Sydenham's chorea patients. J Neuroimmunol. 2004;150(1-2):157-62. doi:10.1016/j.jneuroim.2004.01.013

7. Brilot F, Merheb V, Ding A, Murphy T, Dale RC. Antibody binding to neuronal surface in Sydenham chorea, but not in PANDAS or Tourette syndrome. Neurology. 2011;76(17):1508-13. doi:10.1212/WNL.0b013e3182181090

8. Teixeira AL, Maia DP, Cardoso F. Treatment of acute Sydenham's chorea with methyl-prednisolone pulse-therapy. Parkinsonism Relat Disord. 2005;11(5):327-30. doi:10.1016/j.parkreldis.2005.02.007

9. Kirvan CA, Swedo SE, Heuser JS, Cunningham MW. Mimicry and autoantibody-mediated neuronal cell signaling in Sydenham chorea. Nat Med. 2003;9(7):914-20. doi:10.1038/nm892
10. Teixeira AL, Guimarães MM, Romano-Silva MA, Cardoso F. Serum from Sydenham's chorea patients modifies intracellular calcium levels in PC12 cells by a complement-independent mechanism. Mov Disord. 2005;20(7):843-45. doi:10.1002/mds.20418

11. Doyle F, Cardoso F, Lopes L, Mendes M, Dias F, Cruz L et al. Infusion of Sydenham's chorea antibodies in striatum with up-regulated dopaminergic receptors: a pilot study to investigate the potential of SC antibodies to increase dopaminergic activity. Neurosci Lett. 2012;523(2):186-9. doi:10.1016/j.neulet.2012.06.073

12. Cardoso F, Vargas AP, Oliveira LD, Guerra AA, Amaral SV. Persistent Sydenham's chorea. Mov Disord. 1999;14(5):805-7. doi:10.1002/1531-8257(199909)14:5<805::AID-MDS1013>3.0.CO;2-P

13. Mix E, Goertsches R, Zett UK. Immunoglobulins: basic considerations. J Neurol. 2006;253(5):v9-17. doi:10.1007/s00415-006-5002-2

14. Dajani AS, Aypub E, Bierman FZ, Bisno AL, Denny RW, Durack DT et al.. Guidelines for the diagnosis of rheumatic fever: Jones criteria, 1992 update. JAMA. 1992;268(15):2069-73. doi:10.1001/jama.1992.03490150121036

15. Jiang $\mathrm{H}$, Chess L. Regulation of immune responses by T cells. N Engl $\mathrm{J}$ Med. 2006;354(11):1166-76. doi:10.1056/NEJMra055446

16. Torres KC, Dutra WO, de Rezende VB, Cardoso F, Gollob KJ, Teixeira AL. Monocyte dysfunction in Sydenham's chorea patients. Hum Immunol. 2010;71(4):351-4. doi:10.1016/j.humimm.2010.01.007

17. Faustino PC, Terreri MT, Rocha AJ, Zappitelli MC, Lederman HM, Hilário MO. Clinical, laboratory, psychiatric and magnetic resonance findings in patients with Sydenham chorea. Neuroradiology. 2003;45(7):456-62. doi:10.1007/s00234-003-0999-8 